Šteh, B., Kalin, J., \& Mažgon, J. (2021). Partnership between teachers and school counsellors for quality learning and work in the community, International Journal of Cognitive Research in Science, Engineering and Education (IJCRSEE), 9(2), 147-159.

Original scientific paper

UDK:

37.091 .12

Received: May, 14.2021

$37.091 .12-057.86$

Revised: June, 18.2021.

Accepted: June, 28.2021.

doi: 10.23947/2334-8496-2021-9-2-147-159

\title{
Partnership Between Teachers and School Counsellors for Quality Learning and Work in the Community
}

\author{
Barbara Šteh $^{1 *}$ (D) , Jana Kalin ${ }^{1}$ (D) , Jasna Mažgon' ${ }^{1 D}$ \\ ${ }^{1}$ University of Ljubljana, Faculty of Arts, Department of Educational Sciences, Slovenia, \\ e-mail: barbara.steh@ff.uni-lj.si; janica.kalin@ff.uni-lj.si; jasna.mazgon@ff.uni-lj.si
}

\begin{abstract}
This article discusses the topic of schools as a learning communities from the perspective of the collaboration of two groups of school workers - teachers and school counsellors. The introduction defines how the concept of schools as learning communities is understood and how it is related to the concept of learning organizations. It also further elaborates on the key characteristics of learning communities. The first premise of the contribution is that through joint effort and collaboration, counsellors and teachers can more efficiently face the practical challenges of their work, both in providing help and encouragement to students and in ensuring better classroom work on the level of the whole school. The second is that they are important partners to each other in their professional development through joint reflections of their educational principles and expectations. The article further focuses on the quality of cooperation between counsellors and teachers in primary and secondary schools in Slovenia. The results of the empirical research show that both groups of school workers tend to evaluate their cooperation as either very good or good while teachers tend to be more satisfied. The questionnaire responses show that teachers believe collaboration can benefit them, however that they frequently leave decisions about work with specific students or classes to the counsellors. Establishing and maintaining partner collaboration is always a challenge, however, it is also crucial for effectively confronting contemporary challenges and ensuring quality learning for all and the contribution thus concludes with guidelines for establishing such a beneficial collaboration.
\end{abstract}

Keywords: partnership, school counsellors, teachers, professional learning community, professional development.

\section{Introduction}

\section{School as a professional learning community}

In complex, knowledge-using societies, the school as an institution should become a professional learning community. In 1990, Senge published a highly influential monograph The Fifth Discipline: The Art and Practice of the Learning Organization. After that, concepts such as learning organization and professional learning community quickly became very popular in the field of education, because they were in line with school reforms and they portrayed the ideal of what schools should be (Field, 2019; Kelchtermans, 2006; Lieberman, 2012; Stoll and Kools, 2017). For example, Hargreaves (2003, p. 132) points out that the "idea of the learning community" should be "at the core of the school's mission". Research literature also increased rapidly, addressing the success of these endeavours (Field, 2019; Lieberman, 2012) and the difficulty of forming such communities, since they are usually at odds with the existing school culture in which teachers are isolated from each other, rarely working in teams and solving problems together (Lieberman, 2012). Furthermore, they are not ready for joint learning and change (Hodkinson and Hodkinson 2003, 2004 see in Admiraal et al., 2019; Welsh et al., 2021). Researchers have similarly focused on conceptualizing learning organizations and identifying their key characteristics. Many authors argue that the concepts are not clearly defined (Marsick and Watkins, 2003 see in Welsh et al., 2021; Stoll and Kools, 2017), and that it is not really clear what a learning organization is (Field, 2019). Additional confusion is caused by the body of research on professional learning communities with emphasis on the community. Stoll and Kools (2017) conclude that emphasizing the significance of the community is at the core of the concept of the school as a learning organization: the emphasis is on mutually supportive relationships; developing shared norms and values; mutual trust; creating a school culture that influences how we perceive reality, approach problems and learning; committed focus on

${ }^{*}$ Corresponding author: jasna.mazgon@ff.uni-lj.si

(c) (i) 2021 by the authors. This article is an open access article distributed under the terms and conditions of the Creative Commons Attribution (CC BY) license (https://creativecommons.org/licenses/by/4.0/). 
Šteh, B., Kalin, J., \& Mažgon, J. (2021). Partnership between teachers and school counsellors for quality learning and work in the community, International Journal of Cognitive Research in Science, Engineering and Education (IJCRSEE), 9(2), 147-159.

teaching and learning, and collective responsibility. The concept of the school as a professional learning community captures the individual, collaborative and collective aspects of professional learning in schools (Admiraal et al., 2019, p. 3).

Field (2019) is particularly critical of the concept of learning organization, claiming that there is no agreement about what the term "learning organization" means, which becomes particularly evident when we try to measure how closely a school resembles a learning organization. She maintains that it is not possible to distinguish between "learning" and "non-learning" organizations and she opposes the use of this term, stating that it is "hollow rhetoric" rather than "attainable reality". The problem arises when we perceive the formation of a learning organization or community as something final and instead of a direction to head in. In this changing global world, we can connect in very different ways, and these new forms of organization are characterized by being loose, flexible, collaborative, and purposeful (Lieberman, 2012). It is important, however, that the formation of different groups due to joint work and learning is always given meaning (Welsh et al., 2021), that we share goals, develop trusting relationships, do research together and seek the best possible solutions to the challenges of everyday practice (Lieberman, 2012).

However, when describing the ideal of the learning organization we too often "ignore the political aspects of learning, and instead make the unrealistic assumptions that the interests of all school staff are, or should be, aligned" (Field, 2019, p. 1112). Although we accept that the development of a learning organization is a necessity for dealing with the rapidly changing external environment anywhere in the world, as indicated by the application of the concept in a wide range of countries, contextual factors should also be considered, from the social climate to the assessment methods of failed trials and innovations (Stoll and Kools, 2017). It is important to be aware that different stakeholders may have different professional beliefs, different goals and interests. The school, along with all its members, is embedded in the wider community in a great variety of ways (Bečaj, 2001; Lupton, 2011; Vec, 2009). It is possible systematically to establish collaboration with individuals and institutions in the community and develop partnerships in cocreating learning opportunities, whereby participants mutually learn, change and create new knowledge (Šteh et al., 2018). We advocate using the concept of learning community precisely because educators can connect in their work in various ways and in different groups, including students, parents as well as individuals and institutions outside the school, share their experiences, solve problems, learn and grow together.

Admiraal et al. (2019) find that the development of professional learning communities requires, in particular, professional learning opportunities as well as collaborative work and learning. Additionally, they emphasize the importance of activities in connection with a shared school vision on learning, change of school organization and learning leadership. It can be concluded that authors are united in emphasizing the formation of a common vision, collaborative culture and opportunities for joint work and learning, creating opportunities for the development of all and especially striving for students' successful learning and their personal development. For example, Talbert (2010) emphasizes that professional community building is not just about creating or defining collaborative work for teachers and other educators. It means "shifting a focus on teaching toward student learning, creating rich knowledge resources and networks, and engendering a social service ethic and mutual accountability" and "changing the way schools and the school system operate and how professionals at all system levels work to foster success for all students" (p. 568). Improvement of teaching practice develops through critical, reflective and constructive inquiry and dialogue (Schlager and Schank, 1997 as cited in Ward and Selvester, 2012). According to Ward and Selvester (2012, p. 112), professional learning communities "provide a social context, network and supportive structure" for the professional development of employees and a continuous improvement of teaching and learning.

One of the basic challenges is to what extent schools provide a learning environment that encourages, enables and provides conditions to establish a professional learning community to the greatest possible degree; another is how to promote quality collaboration between educators at a school. We start from the assumption that educators are key actors in creating opportunities for the mutual learning of and collaboration between the members of the school community and their collaboration with the wider community (Šteh et al., 2018). Head teachers certainly play an important role (see Welsh et al., 2021; Schleicher, 2015; McCarty, Wallin and Boggan, 2014), but in this paper we will focus on the collaboration between counsellors and teachers.

\section{The role of school counsellors and their collaboration with teachers}

In Slovenia, the school counselling service is one of the subsystems of a school, so its primary goal is determined by the primary goal of the school. Different experts (e.g. pedagogues, psychologists, social workers, social pedagogues, special pedagogues, etc.) work in the school counselling service. "It is an 
Šteh, B., Kalin, J., \& Mažgon, J. (2021). Partnership between teachers and school counsellors for quality learning and work in the community, International Journal of Cognitive Research in Science, Engineering and Education (IJCRSEE), 9(2), 147-159.

interdisciplinary professional school service participating in solving complex pedagogical, psychological and social issues in schools concerning everybody attending or working there" (Gregorčič Mrvar et al., 2019, p. 92).

According to Resman (1999) and the Programme guidelines (Programske smernice ..., 2008a, $2008 \mathrm{~b}$ ), school-based counselling work as conceptualized in Slovenia has never been limited to assisting students in their personal development and learning; rather, it is a developmental and preventative service aimed at the development of students, and the school as a whole. As such, it provides not only student counselling, directly helping students with their development, but it also helps indirectly the functioning of the school in terms of planning, implementing and evaluating everyday educational work as well as planning, creating and maintaining favourable conditions for a safe and encouraging educational environment that allows students optimum progress (Programske smernice ..., 2008a, 2008b). This means that the counsellor, in addition to working directly with students, also works intensively with the head teacher, teachers, all the school staff and the other stakeholders who significantly co-create the school environment and the educational work programme. The range and diversity of counsellors' areas of activity suggest a special complexity of their work and presuppose the necessity of collaboration with various individuals inside and outside the school.

It should be taken into account that in accordance with the modern strategy of counselling, an important part of counselling is intended for all students; therefore, counselling should be redirected from purely remedial work to "proactive, preventative and developmental work" (Resman, 2007, p. 125). This attitude directs the counsellor towards collaboration with teachers on the basis of mutual and equal relationships, establishing the so-called "consultation model of collaboration". The work of school counsellors at school and their collaboration with teachers does not reduce or narrow teachers' professional work. It concerns the professional work of both groups of educators and their mutual complementarity and support, which proves to be an important factor in their professional development (see Čepić, Kalin and Šteh, 2019).

The quality of networking and establishing appropriate partnerships between educators includes mutual trust, high professionalism in the performance of work and respect for each other's responsibilities. In the process, partners share responsibility for the process and outcomes (Sheridan, Napolitano and Swearer, 2002). In collaboration, it is important to support each other in the joint effort to develop the individual student and the class as a whole, which depends on the existing school culture while it also influences its formation (Bečaj, 2001; Kelchtermans, 2006). School culture is understood here in Schein's 1985 definition as "the deeper level of basic assumptions and beliefs that are shared by members of an organization, that operate unconsciously, and that define in a basic 'taken-for granted' fashion an organization's view of itself and its environment" (see Kelchtermans, 2006, p. 230). It would be ideal to achieve a collaborative culture, which Hargreaves characterizes as voluntary and spontaneous involvement in joint work, without an external agenda (see Kelchtermans, 2006). By working together, teachers and counsellors can work better in helping and encouraging individual students, as well as in promoting quality learning and teaching in the classroom and, moreover, in forming a class community, fostering interpersonal relationships, developing an inclusive culture and promoting holistic personal development for all students (Gregorčič Mrvar et al., 2020). Teachers are constantly facing the challenges of quality teaching, and this is where their collaboration with counsellors can play a supportive role: following the development of the subject area, introducing new didactic approaches and information and communication technology, taking into account students' individual characteristics, appropriate adaptation of lessons to diverse students, etc. In addition to other teachers, school-based counsellors are especially valuable to teachers, since they are more likely to take on consultation and coordination in this area of work, with due regard for students as partners and co-creators of the educational process.

The counsellor and the teacher are partners in their professional development, in creating opportunities for reflection on work and promoting continuous learning, all of which are foundations of the learning community (Šarić and Šteh, 2019). Collaboration is a demanding task both at the level of professional duties and at the purely personal level of the cooperation between two individuals that they define with their knowledge, responsibility and specific personality traits (Kalin, 2019; Kwakman, 2003, see in Kelchtermans, 2006; Vermunt, 2014). Some typical problems that arise in the interaction between the counsellor and the teacher may relate to excessive and/or unexpressed expectations of each other because they are not sufficiently familiar with each other's tasks and the opportunities they have for their work; experience of work overload; problems at the level of interpersonal communication (noise in communication, misunderstanding); unrelated and uncoordinated work with an individual student or group of students; shifting responsibilities onto each other and ambiguities in the division of roles and responsibilities; a feeling of threat may arise when one of the partners in the collaboration feels that the 
Šteh, B., Kalin, J., \& Mažgon, J. (2021). Partnership between teachers and school counsellors for quality learning and work in the community, International Journal of Cognitive Research in Science, Engineering and Education (IJCRSEE), 9(2), 147-159.

other is interfering in his/her professional field; doubt in each other's competence; lack of competences for teamwork; difficulties in establishing an interpersonal relationship of trust and respect, etc. It is important to raise awareness that many of the problems faced by both teachers and counsellors require long-term and intensive work and that results cannot be expected immediately (Kalin, 2004, 2019). They both need to make sense of their joint action, to be aware that this will benefit students and their parents, as well as themselves, since they can share power and responsibility, come up with solutions that they would not come up with on their own, learn together, grow professionally and personally. It is imperative, however, that this accords with the existing school culture and that the school as an organization supports such collaboration at the systemic level. Stoll and Kools (2017, p. 7) highlight the following action-oriented dimensions on which the collective endeavour should be focused: 1) developing and sharing a vision centred on the learning of all students; 2) creating and supporting continuous learning opportunities for all staff; 3) promoting team learning and collaboration among staff; 4) establishing a culture of inquiry, innovation and exploration; 5) embedding systems for collecting and exchanging knowledge and learning; 6) learning with and from the external environment and larger learning systems; and 7) modelling and growing learning leadership.

\section{The purpose of the research study}

The findings discussed in this article are a part of the research study conducted to gain a comprehensive insight into the operation of the school counselling service in Slovenian primary and secondary schools (Gregorčič Mrvar et al. 2020). We were particularly interested in school counsellors' collaboration with various actors in the school, from students and parents to teachers and head teachers. Here, we focus on the quality of collaboration between school counsellors and teachers, focusing on how the collaboration and its characteristics are perceived by school counsellors and teachers. During our study, the following sets of research questions were asked: 1) What is both groups' satisfaction with the collaboration? How do teachers assess the individual characteristics of collaboration with school counsellors? Do teachers differ in their assessments of the collaboration according to years of teaching? 2) How do counsellors assess the frequency of initiatives suggested by themselves as well as teachers and their response? 3) What do counsellors and teachers see as the obstacles to mutual collaboration? Based on the research findings, we developed guidelines for establishing and maintaining quality mutual collaboration between teachers and counsellors.

\section{Materials and Methods}

The study followed the principles of qualitative and quantitative methodologies. The descriptive and causal non-experimental method was used.

The non-random sample of counsellors included 315 counsellors, just under $97 \%$ were women and just over $3 \%$ were men. The average age of the participants was just over 44 years, on average the counsellors had more than 20 years of work experience, of which over 16 years in education. Most counsellors worked in primary schools (just under $77 \%$ ), and a little over $23 \%$ were employed in secondary schools. Of the 70 counsellors who came from secondary schools, 38 (54.3\%) worked in grammar schools (gimnazije), and the rest (45.7\%) in secondary vocational and technical schools.

We asked all the teachers of the randomly selected schools to participate in the research. Thus, 501 teachers responded and were included in the sample. More than a half of the teachers who answered the question about where they taught came from primary schools (251, i.e. $50.3 \%$ ), and slightly less than a half of them taught in secondary schools (248, i.e. $49.7 \%$ ). On average, the surveyed teachers were 46 years old and had been teaching for an average of 20 years.

We designed two questionnaires for the purposes of the research study, which were sent to school counsellors and teachers via a web link in January 2018. To increase the response rate the counsellors and teachers were subsequently invited to participate in the survey, so that the survey lasted until midApril.

The questionnaire for school counsellors contained 48 questions, it included assessment scales and Likert-type attitude scales. It also contained four open-ended questions and eight combined questions. In two questions, we asked the school counsellors to rank individual categories.

The questionnaire for teachers contained 22 questions, including assessment scales and Likerttype attitude scales. In two questions, the teachers had to rank the listed items which were identical in content to the items in the questionnaire for school counsellors. The teachers had the opportunity to express their views on the work of the school counselling service and on work with counsellors in three 
Šteh, B., Kalin, J., \& Mažgon, J. (2021). Partnership between teachers and school counsellors for quality learning and work in the community, International Journal of Cognitive Research in Science, Engineering and Education (IJCRSEE), 9(2), 147-159.

open-ended questions. In this paper, we will present only a section of all the obtained findings in order to answer the research questions asked above.

The data were processed with the SPSS 25.0 software package. We used the frequency distribution of descriptive variables and the basic descriptive statistics of numerical variables (M and SD). Due to the nature of the variables (the questionnaires mostly contained descriptive variables), we used the $\chi^{2}$-test to test the hypotheses.

\section{Results and Discussions}

We start from the assumption that, in addition to cooperation between teachers and students, collaboration between counsellors and teachers is especially important for the quality work and learning of all those involved in the educational process in primary and secondary schools and for school development. This is also specified in the programme guidelines for the counselling service in primary and secondary schools (Programske smernice ..., 2008a, 2008b).

\section{The quality and planning of collaboration between school counsellors and teachers}

Counsellors carry out an important part of their tasks in collaboration with teachers, both in providing assistance to students and in supporting teachers in their educational work. We asked the responding counsellors and teachers about their overall satisfaction with the collaboration. For the teachers, the question referred to the assessment of their collaboration with counsellors, and for the counsellors to collaboration with teachers. On a five-point scale, they could choose between the following assessments: "very good", "good", "neither good nor bad", "bad", "very bad". Due to the low number of responses, we combined the categories "bad" and "very bad".

Table 1.

Satisfaction with collaboration as expressed by teachers (T) and school counsellors (SC)

\begin{tabular}{|c|c|c|c|c|c|c|}
\hline & & \multicolumn{4}{|c|}{ In general, how do you assess your collaboration with teachers/counsellors at the school? } & \multirow[t]{2}{*}{ Total } \\
\hline & & Very good & Good & Neither good nor bad & Bad or very bad & \\
\hline \multirow[t]{2}{*}{$\mathrm{SC}$} & $f$ & 92 & 172 & 22 & 2 & 288 \\
\hline & $f \%$ & 31.9 & 59.7 & 7.6 & 0.7 & $100.0 \%$ \\
\hline \multirow[t]{2}{*}{$\mathrm{T}$} & $f$ & 250 & 183 & 43 & 19 & 495 \\
\hline & $f \%$ & 50.5 & 37.0 & 8.7 & 3.8 & $100.0 \%$ \\
\hline \multirow[t]{2}{*}{ Total } & $f$ & 342 & 355 & 65 & 21 & 783 \\
\hline & $\mathrm{f} \%$ & $43.7 \%$ & 45.3 & 8.3 & 2.7 & 100.0 \\
\hline
\end{tabular}

$\left(\chi^{2}=42.000, g=3 ; p=.000\right)$

In the entire sample of teachers and counsellors, the answers "very good" and "good" prevailed. However, when we examine the results by groups of respondents, the differences between the teachers and school counsellors regarding the assessment of their collaboration are statistically significant. A half of the teachers rated this collaboration as very good, while just under a third of the school counsellors did so. Almost $60 \%$ of the latter rated the collaboration as good. The difference is also noticeable in the "bad" or "very bad" category. This was the opinion of 19 (3.8\%) surveyed teachers and only two surveyed school counsellors. The teachers were more satisfied with working with school counsellors, except for a few individual teachers. On the other hand, the counsellors experienced slightly less satisfaction in the collaboration. The question is what the reason is for such differences. Perhaps the school counsellors' expectations were slightly greater, and they wished for more responsiveness from teachers. The teachers, on the other hand, may not have been aware of on what challenges and how else they could work with school counsellors.

We were interested in whether the teachers participating in the study differed in their assessments of the characteristics of collaborating with counsellors according to years of teaching. According to the years of teaching, the teachers were first divided into 5 categories, following the development of teachers' careers in the Huberman model (1993) and the S-model, which takes into account specifically Slovenian circumstances (Javrh, 2008). Due to the lower representation of teachers with shorter careers, we grouped into the same category those who had entered teaching and faced survival and discovery (up to 3 years of 
Šteh, B., Kalin, J., \& Mažgon, J. (2021). Partnership between teachers and school counsellors for quality learning and work in the community, International Journal of Cognitive Research in Science, Engineering and Education (IJCRSEE), 9(2), 147-159.

teaching) and those who were stabilizing in their role as teachers (4 to 6 years of teaching). Interestingly, this was the group that most often rated their collaboration with counsellors as very good $(66.7 \%)$, which indicates that counsellors were probably an important support for them in entering the profession and in finding their role in school. The differences in years of teaching were the only ones confirmed as statistically significant $(2 \hat{l}=22.204, g=12, p=0.035, n=485$ ) with regard to the general assessment of satisfaction.

In addition to the general assessment of collaboration with school counsellors, we looked for a more accurate insight into how the teachers evaluated existing collaboration with school counsellors. Therefore, we provided them with statements that indicated their (dis)satisfaction with the collaboration and the work of school counsellors, and the teachers rated to what extent they agreed with the statements on a five-point scale, with 1 meaning that they did not agree at all and 5 meaning they strongly agreed with the statement.

Table 2.

Teachers' assessment of collaboration with school counsellors and their work

\begin{tabular}{|c|c|c|c|c|c|c|c|c|c|}
\hline $\begin{array}{l}\text { Assessment of collaboration } \\
\text { with the school counsellors }\end{array}$ & & 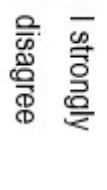 & 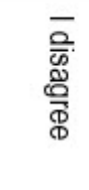 & 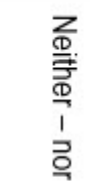 & $\overline{\mathscr{\Xi}}$ & 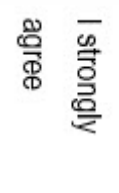 & $\stackrel{\overrightarrow{\underline{D}}}{\underline{\underline{D}}}$ & M & SD \\
\hline $\begin{array}{l}\text { Counsellors impose } \\
\text { additional work on me, often }\end{array}$ & $f$ & 124 & 181 & 107 & 51 & 13 & 476 & 2.26 & 1.05 \\
\hline providing no support. & $f \%$ & 26.1 & 38.0 & 22.5 & 10.7 & 2.7 & 100.0 & & \\
\hline $\begin{array}{l}\text { I think counsellors are too } \\
\text { preoccupied with things that }\end{array}$ & $f$ & 113 & 185 & 101 & 49 & 28 & 476 & 2.36 & 1.13 \\
\hline aren't part of their job. & $f \%$ & 23.7 & 38.9 & 21.2 & 10.3 & 5.9 & 100.0 & & \\
\hline $\begin{array}{l}\text { I don't turn to counsellors } \\
\text { because I don't think they }\end{array}$ & $f$ & 194 & 196 & 51 & 28 & 11 & 480 & 1.89 & .97 \\
\hline can support me in my work. & $f \%$ & 40.4 & 40.8 & 10.6 & 5.8 & 2.3 & 100.0 & & \\
\hline $\begin{array}{l}\text { If you consult counsellors, } \\
\text { you somehow indicate that } \\
\text { you are not in control of the }\end{array}$ & $f$ & 265 & 161 & 30 & 18 & 4 & 478 & 1.61 & .83 \\
\hline $\begin{array}{l}\text { subject and the situation in } \\
\text { the classroom. }\end{array}$ & $f \%$ & 55.4 & 33.7 & 6.3 & 3.8 & 0.8 & 100.0 & & \\
\hline $\begin{array}{l}\text { School counsellors are } \\
\text { generally successful in }\end{array}$ & $f$ & 5 & 27 & 92 & 253 & 87 & 464 & 3.84 & .83 \\
\hline working with students. & $f \%$ & 1.1 & 5.8 & 19.8 & 54.5 & 18.8 & 100.0 & & \\
\hline
\end{tabular}

Table 2 indicates that, on average, the teachers mostly agreed that school counsellors were generally successful in working with students $(M=3.84, S D=0.83)$. On the other hand, on average, they did not agree that counsellors were too preoccupied with things that were not part of their job $(M=2.36$, $\mathrm{SD}=.13$ ) and they similarly did not agree that counsellors imposed additional work on them, often without support $(M=2.26, S D=1.05)$. It is particularly encouraging that they agreed in the smallest share with the statements that they did not turn to counsellors because they thought they could not support them $(M=1.89, S D=0.97)$ and that by consulting counsellors you demonstrated that you did not master the subject and the situation in the classroom $(M=1.61, S D=0.83)$.

The teachers' responses show that they were satisfied with counsellors' work and that they did not perceive working with them as a sign of failure and incompetence. It is important to establish a safe environment and a relationship of mutual trust so that teachers can share with counsellors the concerns, problems and dilemmas they face when working in the classroom or with individual students and parents without feeling threatened (Korthagen, 2017; Rodgers, 2002). Or, as one teacher put it in an open-ended 
question about collaboration: "I take the school counselling service as a place where students and staff can talk honestly, open up about the problems we face in our work, feel heard and, most importantly, feel safe knowing that our trust won't be betrayed." The teacher further wondered whether there was such a counselling service, implying that in some places it was still a challenge for counsellors and teachers to establish the basic conditions for mutual collaboration. Furthermore, what is the quality of this mutual collaboration and is it a partnership in the true sense of the word, as defined by, for instance, Sheridan, Napolitano and Sweareret. (2002), meaning that those involved co-create and share common goals, jointly plan and implement activities, learn from each other, participate to the best of their ability and share responsibility? Or does this satisfaction with the work of counsellors stem more from a clear division of tasks and responsibilities for carrying out these tasks?

Next, we enquired about the extent to which the teachers thought that collaboration with counsellors was defined by the following characteristics: agreeing at the beginning of the year on ways to cooperate, school counsellors' work with individual students in the class and the class as a whole, leaving the decision on work with students or the class to the counsellor, counsellor informing teachers about possible agreements with students or their parents. The teachers responded on a scale from 1 to $5: 1-$ not true at all, 2 - not true, 3 - neither true nor false, 4 - true, 5 - very true.

Table 3.

Some characteristics of collaboration with school counsellors as described by teachers

\begin{tabular}{|c|c|c|c|c|c|c|c|c|c|}
\hline $\begin{array}{l}\text { Characteristics of collaboration } \\
\text { with school counsellors }\end{array}$ & & 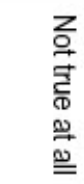 & 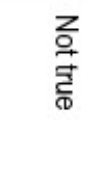 & 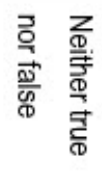 & 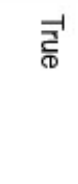 & 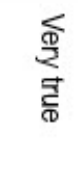 & $\stackrel{\overrightarrow{\underline{d}}}{\underline{\underline{D}}}$ & $M$ & SD \\
\hline $\begin{array}{l}\text { I agree with the counsellor at } \\
\text { the beginning of the year what }\end{array}$ & $f$ & 49 & 55 & 130 & 202 & 53 & 489 & 3.32 & 1.12 \\
\hline $\begin{array}{l}\text { kind of collaboration I would like } \\
\text { in relation to students. }\end{array}$ & $\mathrm{f} \%$ & 10.0 & 11.2 & 26.6 & 41.3 & 10.8 & 100.0 & & \\
\hline $\begin{array}{l}\text { In recent years, the counsellor } \\
\text { has worked with individual }\end{array}$ & $f$ & 7 & 8 & 41 & 253 & 167 & 476 & 4.19 & .78 \\
\hline $\begin{array}{l}\text { students from the classes I } \\
\text { teach. }\end{array}$ & $\mathrm{f} \%$ & 1.5 & 1.7 & 8.6 & 53.2 & 35.1 & 100.0 & & \\
\hline $\begin{array}{l}\text { In recent years, the counsellor } \\
\text { has worked with groups of }\end{array}$ & $f$ & 45 & 78 & 86 & 180 & 86 & 475 & 3.39 & 1.23 \\
\hline $\begin{array}{l}\text { students from the classes I } \\
\text { teach. }\end{array}$ & $f \%$ & 9.5 & 16.4 & 18.1 & 37.9 & 18.1 & 100.0 & & \\
\hline $\begin{array}{l}\text { I leave it up to the counsellor to } \\
\text { decide how he/she will do the }\end{array}$ & $f$ & 8 & 24 & 111 & 209 & 123 & 475 & 3.87 & .91 \\
\hline $\begin{array}{l}\text { counselling work with individual } \\
\text { students or whole classes. }\end{array}$ & $\mathrm{f} \%$ & 1.7 & 5.1 & 23.4 & 44.0 & 25.9 & 100.0 & & \\
\hline $\begin{array}{l}\text { The counsellor informs me } \\
\text { about what has been agreed }\end{array}$ & $f$ & 15 & 12 & 50 & 221 & 166 & 464 & 4.10 & .92 \\
\hline $\begin{array}{l}\text { with individual students or } \\
\text { parents. }\end{array}$ & $\mathrm{f} \%$ & 3.2 & 2.6 & 10.8 & 47.6 & 35.8 & 100.0 & & \\
\hline
\end{tabular}

As seen in Table 3, most teachers agreed ( $88.3 \%$ selected the level true or very true) with the statement that the school counsellor in recent years had dealt with individual students from the classes taught by the teacher. This is also the answer in which the responding teachers were the most consistent $(S D=.78)$. They also largely agreed with the statement that the counsellor informed them of agreements with individual students or their parents. The data confirms the awareness of the importance of mutual communication between teachers and counsellors when working with individual students.

The smallest share of the respondents stated that they agreed with the school counsellor on the collaboration they wanted at the beginning of the school year. The answer may indicate problems 
Šteh, B., Kalin, J., \& Mažgon, J. (2021). Partnership between teachers and school counsellors for quality learning and work in the community, International Journal of Cognitive Research in Science, Engineering and Education (IJCRSEE), 9(2), 147-159.

regarding the degree to which the counsellor's work in classes is systematic and planned. Moreover, it is a question of planning on collaboration at the level of work with classes. This could be the reason why $25.9 \%$ of the teachers stated that it was not true or not true at all that counsellors carried out group forms of work with students from the classes that the teachers taught. The conclusion can be supported by the explanation of one of the teachers: "I am mostly satisfied with the work of the school counselling service, I only miss collaboration related to the burning issue all around us (various workshops and talks for parents, teachers and children). I don't think it's right for them to intervene only when something is already wrong. We urgently need prevention, not just remedy!" A good quarter of the teachers stated that it was very true that they left the decision to the counsellor on how to do counselling work with individual students or the whole class. On the one hand, this can indicate the teachers' trust in the professional competences of counsellors but, on the other hand, it can imply the danger of leaving work with classes and individuals entirely in the hands of counsellors. The partnership model of collaboration presupposes mutual agreement and joint work of all, because it derives from the relationship of reciprocity, equality and equity based on collaboration and consultation (Sheridan, Napolitano and Swearer, 2002). For example, as early as 1997 Resman emphasised the importance of going beyond the notion of counselling as mainly remedial work when certain problems arise at the level of individuals or the class community. It will be necessary to take into account the consequences of the pandemic, which has brought numerous problems and challenges for each of us by stalling the public life we were used to, a year-long school closure, distance learning and life in small family bubbles. There is more psychological irritability, feelings of anxiety, mental health problems, and it is even more difficult for the children and adolescents (as well as their parents or carers) who come from so-called vulnerable groups, that is, from socially underprivileged families, families with difficult interpersonal relationships, for immigrants, students with special needs, mental health problems, etc. (Gregorčič Mrvar et al., 2021; Lee, 2020). Consequently, in the current situation we can expect a great need for remedial treatment, so that counsellors will have even less time for development and prevention, which is the predicament they reported about even before the outbreak of the pandemic (Gregorčič Mrvar et al., 2020).

Among other things, we asked the counsellors about initiatives for collaboration with teachers (see Table 4). A half (50.2\%) of them thought that they were the ones who often took the initiative to collaborate; about a third $(32.3 \%)$ estimated that they always approached teachers when they noticed their interest to collaborate and $56.8 \%$ of them often did so. On the other hand, almost a half $(48.9 \%)$ of the counsellors estimated that they sometimes left the initiative for counselling to teachers and responded only when teachers contacted them; just under a third (31.3\%) did so frequently.

Table 4.

Frequency of initiatives and responses by teachers and counsellors as assessed by counsellors

\begin{tabular}{|c|c|c|c|c|c|c|c|}
\hline $\begin{array}{l}\text { Frequency of initiatives to work with } \\
\text { teachers }\end{array}$ & & $\underset{\mathbb{\Phi}}{\mathbb{\mathbb { Q }}}$ & 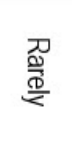 & 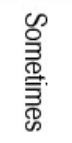 & 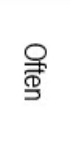 & $\sum_{\infty}^{\infty}$ & $\stackrel{\overrightarrow{\underline{a}}}{\stackrel{\underline{\underline{O}}}{2}}$ \\
\hline $\begin{array}{l}\text { The initiative is mine. I inform teachers } \\
\text { about the work in advance and offer the }\end{array}$ & $f$ & 1 & 17 & 111 & 143 & 13 & 285 \\
\hline $\begin{array}{l}\text { possibility of consultation, and they either } \\
\text { accept it or not. }\end{array}$ & $f \%$ & 0.4 & 6.0 & 38.9 & 50.2 & 4.6 & 100.0 \\
\hline When I notice that a teacher expresses & $f$ & 0 & 0 & 31 & 162 & 92 & 285 \\
\hline interest in participating, I approach her/him. & $\mathrm{f} \%$ & 0.0 & 0.0 & 10.9 & 56.8 & 32.3 & 100.0 \\
\hline $\begin{array}{l}\text { I leave the initiative for collaboration to } \\
\text { teachers. I consult them when they }\end{array}$ & $f$ & 2 & 44 & 139 & 89 & 10 & 284 \\
\hline approach me. & $f \%$ & 0.7 & 15.5 & 48.9 & 31.3 & 3.5 & 100.0 \\
\hline I feel that teachers are embarrassed to & $f$ & 125 & 107 & 42 & 9 & 1 & 284 \\
\hline approach me for consultation. & $\mathrm{f} \%$ & 44.0 & 37.7 & 14.8 & 3.2 & 0.4 & 100.0 \\
\hline $\begin{array}{l}\text { I feel that my efforts for professional } \\
\text { collaboration is seen as redundant by } \\
\text { teachers, that they do not appreciate them. }\end{array}$ & $\mathrm{f} \%$ & 104 & 39.0 & 18.8 & 4.3 & 0.4 & 100.0 \\
\hline
\end{tabular}


The assessments of the majority of the responding counsellors show that the basic conditions for quality mutual collaboration are mostly in place in schools (Table 4). Forty-four percent of the counsellors stated that they never felt that teachers were embarrassed to approach them for consultation, or that it was only rarely the case (37.7\%). Of course, teachers should also be asked about this. Most counsellors $(39 \%)$, on the other hand, rarely felt that their efforts for professional collaboration were seen as redundant and not appreciated by teachers, while $37.5 \%$ said that they never had this feeling. At the same time, almost a fifth (18.1\%) stated that they sometimes felt this. In these cases, it would be important to clarify mutual expectations, and it is the task of counsellors to present to teachers their work and the areas where they could participate to improve educational work.

We also asked the counsellors about how teachers accepted their efforts to collaborate and consult each other. The vast majority of the counsellors (87.9\%) estimated that teachers most often accepted professional collaboration and joint efforts in resolving specific situations. Only 5\% of the counsellors estimated that teachers most often reacted as if they had been forced to do something, while three $(1.1 \%)$ reported feeling that teachers did not care. Six percent of the counsellors explained the most common reaction to their efforts for collaboration and consultation under the "other" answer. The latter most often highlighted that teachers reacted differently to their initiatives for collaboration, that some were willing to cooperate, that they sought help, while others perceived this as interference or additional work. It is probably crucial that everyone involved is willing to learn together and change the established patterns of behaviour, beliefs and views on their roles as educators, changing the perspective on both teaching and their own learning (Makovec, 2018; Vermunt, 2014; Welsh et al., 2021). This willingness to learn, in conjunction with other personal factors such as prior experience, professional identity, self-confidence, tolerance for uncertainty, etc., depends on contextual factors, too (Vermunt, 2014). The organization of the learning environment is of particular importance (do the structures allow for collaborative work and learning, collaboration in teams) (Admiraal et al., 2019; Bakkenes, Vermunt and Wubbels, 2010 see in Vermunt, 2014; Stoll and Kools, 2017; Welsh et al., 2021) as is the culture of the school (is it competitive, in which educators have to prove themselves constantly, does directive leadership prevail, or is it open to collaboration, innovation and exploration) (Stoll and Kools, 2017).

\section{Obstacles to quality collaboration between school counsellors and teachers}

The challenge of any collaboration is how to overcome obstacles that arise for various reasons from very objective ones to those related to the personal traits of participating individuals, their knowledge, views, beliefs, attitudes, and values. Today, we expect educators to have developed skills in working in teams of experts and cooperating with others inside and outside the school. In 1995, Fullan wrote that teachers were expected to "become committed to, skilled at, and involved in (indeed helping to create) collaborative work cultures inside and outside the school" (Fullan, 1995, p. 233), and the same applies to counsellors.

We provided the teachers and counsellors in our study with some main obstacles for them to assess. The answers they could give were: 1 - no obstacle, 2 - a minor obstacle, 3 - an obstacle, 4 - a major obstacle, $x-$ I cannot assess. We were interested in whether the teachers' and counsellors' answers regarding obstacles to collaboration differed in any way. As the data in Table 5 show, the differences between the counsellors and teachers in the obstacle assessment are statistically significant in all the items. 
Šteh, B., Kalin, J., \& Mažgon, J. (2021). Partnership between teachers and school counsellors for quality learning and work in the community, International Journal of Cognitive Research in Science, Engineering and Education (IJCRSEE), 9(2), 147-159.

Table 5.

Views of school counsellors (SC) and teachers (T) on obstacles to collaboration

\begin{tabular}{|c|c|c|c|c|c|c|c|c|}
\hline \multirow{2}{*}{\multicolumn{3}{|c|}{ Obstacles to collaboration }} & \multicolumn{5}{|c|}{ Counsellors' and teachers' assessments of individual statements } & \multirow{3}{*}{$\begin{array}{c}\chi^{2 \text {-tes }} \\
\mathbf{p} \\
18.491\end{array}$} \\
\hline & & & \multirow{2}{*}{$\begin{array}{c}\text { no obstacle } \\
78\end{array}$} & \multirow{2}{*}{$\begin{array}{c}\text { a minor } \\
\text { obstacle } \\
112\end{array}$} & \multirow{2}{*}{$\begin{array}{c}\text { an obstacle } \\
58\end{array}$} & \multirow{2}{*}{$\begin{array}{c}\text { a major } \\
\text { obstacle }\end{array}$} & \multirow{2}{*}{$\begin{array}{c}\mathrm{N} \\
278\end{array}$} & \\
\hline \multirow{4}{*}{$\begin{array}{l}\text { Lack of knowledge } \\
\text { of each other's work } \\
\text { and tasks }\end{array}$} & $\mathrm{SC}$ & $f$ & & & & & & \\
\hline & & $f \%$ & 28.1 & 40.3 & 20.9 & 10.8 & 100.0 & .000 \\
\hline & $\mathrm{T}$ & f & 175 & 139 & 108 & 23 & 445 & \\
\hline & & $\mathrm{f} \%$ & 39.3 & 31.2 & 24.3 & 5.2 & 100.0 & \\
\hline \multirow{4}{*}{$\begin{array}{l}\text { Overburdening with } \\
\text { work in both, the } \\
\text { teachers and the } \\
\text { counsellors }\end{array}$} & $\mathrm{SC}$ & f & 12 & 58 & 111 & 99 & 280 & 16.547 \\
\hline & & $\mathrm{f} \%$ & 4.3 & 20.7 & 39.6 & 35.4 & 100.0 & .001 \\
\hline & $\mathrm{T}$ & f & 55 & 111 & 159 & 128 & 453 & \\
\hline & & $f \%$ & 12.1 & 24.5 & 35.1 & 28.3 & 100.0 & \\
\hline \multirow{4}{*}{$\begin{array}{l}\text { Poor } \\
\text { communication }\end{array}$} & $\mathrm{SC}$ & $f$ & 107 & 107 & 52 & 13 & 279 & 30.622 \\
\hline & & f\% & 38.4 & 38.4 & 18.6 & 4.7 & 100.0 & .000 \\
\hline & $T$ & $f$ & 243 & 109 & 60 & 47 & 459 & \\
\hline & & f\% & 52.9 & 23.7 & 13.1 & 10.2 & 100.0 & \\
\hline \multirow{4}{*}{$\begin{array}{l}\text { Bad experiences of } \\
\text { collaboration }\end{array}$} & $\mathrm{SC}$ & $f$ & 153 & 95 & 21 & 8 & 277 & 36.101 \\
\hline & & $f \%$ & 55.2 & 34.3 & 7.6 & 2.9 & 100.0 & .000 \\
\hline & $T$ & $f$ & 284 & 77 & 61 & 36 & 458 & \\
\hline & & $\mathrm{f} \%$ & 62.0 & 16.8 & 13.3 & 7.9 & 100.0 & \\
\hline \multirow{4}{*}{$\begin{array}{l}\text { Different } \\
\text { expectations about } \\
\text { collaboration }\end{array}$} & $\mathrm{SC}$ & $f$ & 56 & 123 & 68 & 33 & 280 & 50.029 \\
\hline & & f\% & 20.0 & 43.9 & 24.3 & 11.8 & 100.0 & .000 \\
\hline & $\mathrm{T}$ & $f$ & 209 & 125 & 89 & 39 & 462 & \\
\hline & & f\% & 45.2 & 27.1 & 19.3 & 8.4 & 100.0 & \\
\hline \multirow{4}{*}{$\begin{array}{l}\text { Differences in } \\
\text { professional views } \\
\text { on work in the } \\
\text { classroom and with } \\
\text { students }\end{array}$} & SC & $f$ & 59 & 120 & 70 & 29 & 278 & 49.119 \\
\hline & & f\% & 21.2 & 43.2 & 25.2 & 10.4 & 100.0 & .000 \\
\hline & $\mathrm{T}$ & $f$ & 212 & 127 & 78 & 34 & 451 & \\
\hline & & $f \%$ & 47.0 & 28.2 & 17.3 & 7.5 & 100.0 & \\
\hline
\end{tabular}

In all the cases of possible obstacles, except for prior bad experiences of collaboration, the school counsellors saw more obstacles to collaboration than the teachers. The counsellors thus saw more obstacles than the teachers in the lack of knowledge about each other's work and tasks, in the workload on both sides, in differences in expectations about collaboration and in differences in professional views on work in the classroom and with students. For the most part, however, they both agreed that they were least hindered by bad experiences of mutual collaboration and poor mutual communication. The teachers were even more likely to say that this did not present an obstacle at all. This is certainly a good indicator because effective communication between educators is one of the key conditions for quality collaboration and for facing work challenges jointly (Welsh et al., 2021). Without mutual respect, genuine interest in each other's work, worries and perspective - as well as trust in each other's strength and competence there can be no real foundations for quality collaboration. Or, as one of the teachers put it: "Collaboration depends on both people's willingness to listen to each other." Many obstacles to mutual collaboration (such as differences in professional views and expectations, lack of knowledge of each other's work and tasks) are largely related to clarifying the role of counsellors and teachers and their expectations of each other through conversations between educators.

As far as educators' overburdening is concerned, it would make sense to consider setting priorities for joint work; we assume that both teachers and counsellors would save some time and avoid extra work if they found time to agree on how to share work and collaborate in individual areas of work. This, in turn, requires willingness to cooperate with each other and awareness that the effort and time invested will bring benefits to all stakeholders in the educational process. First, quality collaboration can lead to a better professional response to and work with individual students, classes and parents when teachers and 
counsellors face moral, social and emotional dilemmas in our postmodern societies. Quality collaboration contributes to good interpersonal relationships and a culture of collaboration and, finally, it enables professional development for both teachers and counsellors. The following statement illustrates that some professional communities have achieved this: "It's great to work with colleagues from our counselling service and colleagues from other schools, because we're aware that work is successful for all stakeholders only through collaboration and teamwork. I like it because we debate a lot constructively and look for solutions."

\section{Conclusions}

The findings of our study show that both counsellors and teachers are generally satisfied with their collaboration, especially when there are very clear boundaries between their tasks and responsibilities. However, partnership - when they jointly plan activities and goals, participate in these activities and share responsibility - is much more difficult to achieve. The programme guidelines for primary, grammar schools, lower and upper vocational schools, technical schools and boarding schools (Programske smernice ..., 2008a, 2008b) emphasize the importance of consultation, planning, implementing and evaluating schoolwork together. This is related to certain basic principles of the work of the school counselling service which must be taken into account when collaborating with teachers: in particular, "the principle of interdisciplinarity, the principle of a holistic approach and the principle of cooperation in counselling relationships" (Programske smernice ..., 2008a, p. 18). Based on the findings, we can assume that in these areas in the future counsellors will face challenges in collaboration with teachers, to which they will be able to respond with good quality solutions only by planning properly their priorities and by (co-)working in partnerships with each other. In line with our theoretical starting points and empirical research, we highlight some important guidelines for establishing and maintaining quality mutual collaboration between teachers and school counsellors:

- striving to create shared values and vision,

- awareness of collective responsibility,

- constant (continuous) clarification of mutual expectations and competences,

- awareness of the need for and importance of teamwork of both groups of educators, conditions

- flexible exploration of appropriate ways of collaboration, ensuring time and organizational

- enabling support for each other in conducting research on one's own practice, and developmental tasks and projects,

- ensuring collaboration that is mutually beneficial and for the benefit of students (as well as their parents and the school community),

- developmental orientation and innovation,

- enabling (encouraging, supporting) supervision, monitoring, evaluating and critically reflecting on one's own work,

- establishing an appropriate collaborative climate and opportunities for the professional development of all.

We believe that the basis for such partnership is the formation of appropriate interpersonal relationships, trust and respect at personal and professional levels (see e.g. Kelchtermans, 2006; Hord, 1997; Stoll et al., 2006). As a consequence, a community of teachers and other educators is established and the strength of the professional community is activated - the professional community as a learning community in which individuals make progress through collaboration with others, through shared experiences and knowledge and with the aim of achieving excellence (see Kalin, 2019). Stoll and Kools (2016) underline that in order to form a learning community it is necessary to provide the four T's: trust, time, technology and thinking together. Constant and critical reflection ensures quality work and progress for both individuals and the entire community (Šarić, 2013; Šarić and Šteh, 2017, 2019). The basic starting point for the implementation of these guidelines is the acceptance and anticipation of change and willingness to learn, work and create together.

\section{Acknowledgements}

The authors acknowledge the financial support from the Slovenian Research Agency (research core funding No. P5-0174, Pedagogical and andragogical studies - Learning and education for a good quality life in community). 
Šteh, B., Kalin, J., \& Mažgon, J. (2021). Partnership between teachers and school counsellors for quality learning and work in the community, International Journal of Cognitive Research in Science, Engineering and Education (IJCRSEE), 9(2), 147-159.

\section{Conflict of interests}

The authors declare no conflict of interest.

\section{References}

Admiraal, W., Schenke, W., De Jong, L., Emmelot, Y., \& Sligte, H. (2019). Schools as professional learning communities: what can schools do to support professional development of their teachers?. Professional development in education, 1-15. https://doi.org/10.1080/19415257.2019.1665573

Bečaj, J. (2001). Razrednik in šolska kultura [The class teacher and school culture]. Sodobna pedagogika, 52(1), 32-44.

Čepić, R., Kalin, J. \& Šteh, B. (2019). Teachers' professional development: Context, perspectives, and challenges. In R. Čepić \& J. Kalin (Eds.), Teachers' professional development, Status and transversal competencies (pp. 133-158). Ljubljana University Press, Faculty of Arts, and Faculty of Teacher Education, University of Rijeka. http://www.dlib.si/stream/ URN:NBN:SI:doc-6T0QRKSD/b2e10276-8d3c-4304-b933-68cd95f4bf7c/PDF

Field, L. (2019). Schools as learning organizations: hollow rhetoric or attainable reality?. International journal of educational managmen, 33(5), 1106-1115. https://doi-org.nukweb.nuk.uni-lj.si/10.1108//JEM-05-2018-0165

Fullan, M. (1995). The school as a learning organization: Distant dreams. Theory into practice, 34(4), 230-235. Retrieved from https://www.jstor.org/stable/1476595

Gregorčič Mrvar, P., Jeznik, K., Šarić, M. \& Šteh, B. (2021). Soočanje svetovalnih delavk in delavcev v vzgojno-izobraževalnih ustanovah z epidemijo covida-19 [Counsellors' coping with Covid-19 epidemics]. Sodobna pedagogika, 72 (Special issue), 150-167.

Gregorčič Mrvar, P., Jeznik, K., Kalin, J. Kroflič, R. Mažgon, J., Šarić, M., \& Šteh, B. (2020). Šolska svetovalna služba: stanje in perspektive [School counselling service: current state and perspective]. Znanstvena založba Filozofske fakultete Univeze v Ljubljani [Ljubljana University Press, Faculty of Arts].

Gregorčič Mrvar, P., Resman, M., Kalin, J., \& Mažgon, J. (2019). Cooperation between head teachers and professional school counsellors in Slovenian schools. Management: journal of contemporary management issues, 24(Special issue), 89106. https://doi.org/10.30924/mjcmi.24.si.6

Hargreaves, A. (2003). Teaching in the Knowledge Society: Education in the Age of Insecurity. New York and London: Teachers College Press, Teachers College, Columbia University. Retrieved from https://citeseerx.ist.psu.edu/viewdoc/download ?doi=10.1.1.533.6940\&rep=rep1\&type=pdf

Hord, S. M. (1997). Professional learning communities: Communities of continuous inquiry and improvement. Austin, TX: Southwest Educational Development Laboratory. Retrieved from https://files.eric.ed.gov/fulltext/ED410659.pdf

Huberman, M. (1993). The life of teachers. New York: Teacher college press.

Javrh, P. (2008). Spremljanje in načrtovanje razvoja kariere učiteljev po S-modelu [Monitoring and planning the development of teachers' careers according to the S-model] (1 ${ }^{\text {st }}$ ed.). Ljubljana: Pedagoški inštitut [Educational Research Institute].

Kalin, J. (2004). Sodelovanje učitelja in razrednika s svetovalno službo [Collaboration between teachers and class teachers with the school counselling service]. Šolsko svetovalno delo, 9(3/4), 27-32.

Kalin, J. (2019). Vloga pedagoga pri sodelovanju z razredniki in oddelčno skupnostjo [A Pedagogue's Role in Collaborating with the Class Teacher and the Class Community]. Sodobna pedagogika, 70(1), 70-86. Retrieved from https://www. sodobna-pedagogika.net/arhiv/nalozi-clanek/?id=1532

Kelchtermans, G. (2006). Teacher collaboration and collegiality as workplace conditions. A review. Zeitschrift für Pädagogik, 52(2), 220-237. Retrieved from https://www.pedocs.de/volltexte/2011/4454/pdf/ZfPaed_2006_2_Kelchtermans_ Teacher_collaboration_collegiality_D_A.pdf

Korthagen, F. A. J. (2017). Inconvenient truths about teacher learning: towards professional development 3.0. Teachers and Teaching: theory and practice, 23(4), 387-405. https://doi.org/10.1080/13540602.2016.1211523

Lee, J. (2020). Mental health effects of school closures during COVID-19. Child \& Adolescent Health, 4(6), 421. https://doi. org/10.1016/S2352-4642(20)30109-7

Lieberman, A. (2012). Learning about professional communities. In C. Day (Ed.), The Routledge International Handbook of Teacher and School Development (pp. 469-475). London and New York: Routledge, Taylor and Francis Group.

Lupton, R. (2011). Local context, social relations and school organisation. In C. Day (Ed.). Routledge International Handbook of Teacher and School Development (pp. 194-203). London: Routledge. https://doi.org/10.4324/9780203815564.ch15

Makovec, D. (2018). The teacher's role and professional development. International Journal of Cognitive Research and Science, Enginneering and Education, 6(2), 33-45. https://doi.org/10.5937/ijcrsee1802033M

McCarty, D., Wallin, P., \& Boggan, M. (2014). Shared leadership model for 21 st century schools: Principal and counselor collaborative leadership. In National forum of educational administration and supervision journal, pp. 1-9. Retrieved from http://www.nationalforum.com/Electronic\%20Journal\%20Volumes/McCarty,\%20Darla\%20Shared\%20Leadership\%20 NFEASJ\%20V32\%20N4\%202014.pdf

Programske smernice. Svetovalna služba v osnovni šoli [Programme guidelines. Counselling service in primary schools]. (2008a). Ljubljana: Zavod Republike Slovenije za šolstvo [National Education Institute Slovenia]. Retrieved from http:// www.mizs.gov.si/fileadmin/mizs.gov.si/pageuploads/ministrstvo/Publikacije/Programske_smernice_OS.pdf

Programske smernice. Svetovalna služba v gimnazijah, nižjih in srednjih poklicnih šolah ter strokovnih šolah in dijaških domovih [Programme guidelines. Counselling service in grammar schools, lower and upper vocational schools and technical schools and boarding schools]. (2008b). Ljubljana: Zavod Republike Slovenije za šolstvo [National Education Institute Slovenia]. Retrieved from http://eportal.mss.edus.si/msswww/programi2019/programi/media/pdf/smernice/ Programske_smernice_SS.pdf

Resman, M. (1997). Oddelek, učitelj in svetovalni delavec [Class, teacher and school counsellor]. Sodobna pedagogika, 48(3/4), 121-135.

Resman, M. (1999). Pojem in karakteristike šolskega svetovanja [The concept and characteristics of school counselling]. In M. Resman, J. Bečaj, T. Bezić, G. Čačinovič Vogrinčič, \& J. Musek, Svetovalno delo v vrtcih, osnovnih in srednjih šolah 
[Counselling in preschools, primary and secondary schools] (pp. 67-84). Ljubljana: Zavod Republike Slovenije za šolstvo [National Education Institute Slovenia].

Resman, M. (2007). Vzgojni koncept se uresničuje v oddelkih (Zakaj svetovalno pozornost usmeriti v oddelek) [Educational concept is implemented in classes (Why direct counselling attention to the class)]. Sodobna pedagogika, 58(Special issue), 122-139.

Rodgers, C. (2002). Defining reflection: Another look at John Dewey and reflective thinking. Teachers College Record, 104(4), 842-866. Retrieved from https://www.tcrecord.org/content.asp?contentid=10890

Schleicher, A. (2015). Schools for 21st-Century Learners. Strong Leaders, Confident Teachers, Innovative Approaches. International Summit on the Teaching Profession, OECD Publishing. https://doi.org/10.1787/9789264231191-en

Senge, P. M. (1990). The Fifth Discipline. The art and practice of the learning organization. London: Random House.

Sheridan, S. M., Napolitano, S. A., \& Swearer, S. M. (2002). Best practices in school-community partnerships. In A. Thomas \& J. Grimes (Eds.). Best practices in school psychology IV (pp. 321-336). Bethesda, MD: National Association of School Psychologists.

Stoll, L., Bolam, R., McMahon, A., Wallace, M., \& Thomas, S. (2006). Professional learning communities: a review of the literature. Journal of Educational Change, 7(4), 221-258. https://doi.org/10.1007/s10833-006-0001-8

Stoll, L., \& Kools. M. (2017). The school as a learning organisation: a review revisiting and extending a timely concept. Journal of Professional Capital and Community, 2(1), 2-17. https://doi.org/10.1108/JPCC-09-2016-0022

Šarić, M. (2013). Jedrna refleksija: poglabljanje refleksije v strokovnem razvoju [Core reflection: deepening reflection in professional development]. Šolsko svetovalno delo, 17(3/4), 81-88.

Šarić, M. in Šteh, B. (2017). Critical reflection in the professional development of teachers: challenges in possibilities. CEPS journal: Center for Educational Policy Studies Journal, 7(3), 67-85. https://www.cepsj.si/index.php/cepsj/article/ view/288/173

Šarić, M. in Šteh, B. (2019). Implementing Reflective Practice to Improve Our Participation in the Community. V: K. Skubic Ermenc in B. Mikulec (ur.). Building Inclusive Communities through Education and Learning. Newcastle, UK: Cambridge Scholars Publishing, 117-133.

Šteh, B., Muršak, J., Mažgon, J., Kalin, J., \& Gregorčič Mrvar, P. (2018). School - Home - Community: Inevitable Connections. Berlin: Peter Lang.

Talbert, J.E. (2010). Professional learning communities at the crossroads: how systems hinder or engender change. In A. Hargreaves, A. Lieberman, M. Fullan \& D. Hopkins (Eds.), Second international handbook of educational change (pp. 555-571). Dordrecht, Heidelberg, London, New York: Springer.

Vec, T. (2009). Partnerstvo med šolo in starši - enoznačni cilj in različnost poti. [Partnership between the school and parents an unambiguous goal and different paths.] In F. Cankar \& T. Deutsch (Eds.), Šola kot stičišče partnerjev. Sodelovanje šole, družine in lokalnega okolja pri vzgoji in izobraževanju otrok. [The school as a meeting point of partners: The cooperation among the school, the family and the local environment in children's education.] (pp. 63-82). Ljubljana: Zavod RS za šolstvo [National Education Institute Slovenia].

Vermunt, J. D. (2014). Teacher Learning and Professional Development. In S. Krolak-Schwerdt, S. Glock \& M. Böhmer (Eds.), Teachers' Professional Development: Assessment, Training, and Learning (pp.79-95). Rotterdam, Boston, Taipei: Sense Publishers.

Ward, H.C., \& Selvester, P.M. (2012). Faculty learning communities: improving teaching in higher education. Educational Studies, 38(1), 111-121. https://doi.org/10.1080/03055698.2011.567029

Welsh, R., Williams, S., Bryant, K., \& Berry, J. (2021). Conceptualization and challenges: examining district and school leadership and schools as learning organizations. The Learning Organization, ahead-of-print. https://doi.org/10.1108/ TLO-05-2020-0093 
Šteh, B., Kalin, J., \& Mažgon, J. (2021). Partnership between teachers and school counsellors for quality learning and work in the community, International Journal of Cognitive Research in Science, Engineering and Education (IJCRSEE), 9(2), 147-159. 